\title{
PROJETO INTEGRADOR: UMA FERRAMENTA DE ENSINO/ APRENDIZAGEM EM CURSOS TÉCNICOS
}

Antonio Ricardo Salvador ${ }^{1}$

Andresa Jaqueline Toassi

\begin{abstract}
RESUMO
Frente às características do cenário contemporâneo, o contexto educacional precisa avaliar frequentemente seus métodos de ensino, a fim de adequar-se às exigências sociais. Assim, o SENAI/SC instituiu em sua grade curricular, a elaboração de "Projetos Integradores". Esta ferramenta didático-pedagógica compreende o planejamento e aplicação de um projeto que englobe as diversas disciplinas do semestre, promovendo a multidisciplinaridade. $O$ intuito desta atividade é o estabelecimento de relações entre teoria e prática, visando, a resolução de problemas e a aplicação do conhecimento adquirido em situações reais. Partindo destas considerações, este artigo tem o objetivo de analisar o papel do projeto integrador no processo de ensino/aprendizagem dos alunos dos cursos técnicos do SENAI/SC, da cidade de Rio do Sul, segundo as concepções dos docentes. Para tanto, foi realizada uma pesquisa documental nos materiais que norteiam o referido instrumento, seguida pela observação e acompanhamento da realização do Projeto Integrador em uma turma. Posteriormente, foi aplicado um questionário, junto aos docentes dos cursos técnicos, a fim de obter dados referentes às suas concepções. Pela observação efetuada e através da análise quantitativa e qualitativa das respostas, pode-se perceber que a maioria dos professores concebe o Projeto Integrador como uma ferramenta de suma importância para o processo de ensino/aprendizagem, pois, além de ampliar o conhecimento do educando através da ligação entre teoria e prática, serve de incentivo à interdisciplinaridade, estimula o desenvolvimento da criatividade e promove o trabalho em equipe, tanto por parte dos discentes, como também do corpo docente.
\end{abstract}

Palavras-chave: Educação. Projeto Integrador. Aprendizagem. Docentes.

\footnotetext{
${ }^{1}$ Especialista, e-mail: antonioricardo@sc.senai.br

2 Mestre, e- mail: andresasc@yahoo.com.br
} 


\section{INTRODUÇÃO}

O contexto contemporâneo educacional caracteriza-se pela pluralidade e complexidade, apresentando características distintas de outras épocas. Assim, a escola, por ser o local onde as diversas concepções dos fenômenos sociais e da vida humana são analisadas e discutidas, de maneira formal e sistematizada nas diferentes disciplinas; deve acompanhar o processo de desenvolvimento da sociedade e contemplar as necessidades que estas mudanças pressupõem.

Diante deste cenário, os educadores, se veem frente a desafios diferenciados, entre eles, o de equilibrar as exigências de sistematização dos conteúdos e a lógica disciplinar, com a realidade vivenciada pelos alunos. Este fato faz com que o diálogo entre as disciplinas seja imprescindível, ao possibilitar a construção de práticas pedagógicas coerentes com o contexto vivenciado, além de efetivamente pautadas no comprometimento com o aprendizado dos educandos.

Tendo em vista as concepções desenvolvidas até o momento, este estudo visa analisar uma das ferramentas de ensino utilizadas pelo Serviço Nacional de Aprendizagem Industrial de Santa Catarina (SENAI/SC), aplicada na unidade de Rio do Sul, qual seja, o Projeto Integrador. Este instrumento educacional tem como objetivo ampliar os conhecimentos dos alunos e desenvolver as competências previstas nas Unidades Curriculares, ao buscar estabelecer ligações efetivas entre a teoria e a prática, através da multidisciplinaridade, da resolução de problemas do cotidiano organizacional e/ou da elaboração de protótipos.

O Projeto Integrador compreende o planejamento e a aplicação de um trabalho - que abranja tanto os conhecimentos teóricos como práticos - através da integração das disciplinas de determinado período letivo, o qual, dependendo da turma, dos docentes ou ainda dos objetivos, pode abranger um semestre ou dois. Ademais, este busca, preferencialmente, a resolução de problemáticas reais de uma área de estudo específica e a promoção da multidisciplinaridade entre os docentes. $O$ instrumento em questão visa, portanto, contextualizar os conhecimentos através da articulação entre teoria e prática; além de possibilitar a avaliação e vivência do discente, sob circunstâncias similares a situações reais de atuação profissional.

Com base nestas considerações, a intenção principal deste estudo foi analisar o papel do Projeto Integrador no processo de ensino/aprendizagem dos alunos dos cursos técnicos do SENAI/SC, na Unidade de Rio do Sul, segundo as concepções dos docentes; visando averiguar sua importância e as contribuições que ele acarreta à aprendizagem dos discentes. Os métodos utilizados para atingir as metas consistiram em uma análise dos projetos integradores, bem como, dos documentos elaborados pelo SENAI/SC, que preconizam e estabelecem as diretrizes dos mesmos. 
Posteriormente, foi aplicado um questionário junto aos docentes, visando identificar suas concepções acerca deste instrumento. Concomitante a este processo, houve o acompanhamento da aplicação do Projeto Integrador em uma turma de alunos do Curso Técnico em Eletrotécnica, a fim de proporcionar maior veracidade ao estudo e com o intuito de verificar, de forma empírica, como efetivamente ocorre esta situação.

De modo geral, os resultados obtidos apontam que o Projeto Integrador, como qualquer ferramenta de ensino, apesar de possuir itens a serem aperfeiçoados, constitui-se como um instrumento fundamental e bastante útil à prática educacional, não vendo o conhecimento como algo estático e segregado, mas como um processo dinâmico, complexo e abrangente.

\subsection{Objetivo geral}

Analisar o papel do Projeto Integrador no processo de ensino/aprendizagem dos alunos dos cursos técnicos do SENAI/SC, de Rio do Sul, segundo a opinião dos docentes.

\subsection{Objetivos específicos}

a) avaliar as concepções dos professores dos cursos técnicos a respeito dos Projetos Integradores.

b) identificar os aspectos positivos e negativos da aplicação do referido Projeto Integrador.

c) averiguar a importância e as contribuições que este Projeto Integrador efetivamente acarretam à aprendizagem aos discentes.

\section{O CAMINHO - METODOLOGIA DO ESTUDO}

O método consiste no caminho percorrido para investigar determinados aspectos da realidade, variando de acordo com os objetivos e delineamentos propostos pelo estudo (RICHARDSON, 1999). A pesquisa, deste modo, apresenta uma abordagem quantiqualitativa, ao utilizar tanto a análise de dados subjetivos como a mensuração das informações coletadas. 
O estudo, além de explicativo, apresenta-se como uma pesquisa documental, uma vez que sua conclusão baseia-se na análise de documentos elaborados pela instituição estudada (GIL, 1999). Caracteriza-se também como uma pesquisa de campo, pois o processo de investigação acontece no próprio local onde o fenômeno incide, contando, inclusive com a presença do pesquisador efetivamente em campo.

Na época em que foi realizada a pesquisa, primeiro e segundo semestres de 2010 e primeiro semestre de 2011, o SENAI/SC em Rio do Sul possuía 6 (seis) cursos técnicos em andamento, abrangendo um total de 220 (duzentos e vinte) alunos e, consequentemente, havia o desenvolvimento de 6 (seis) projetos integradores, um em cada turma. Porém, tendo em vista os objetivos do estudo, optou-se por acompanhar, de forma mais específica, a aplicação de um dos projetos, sendo o realizado no Curso de Eletrotécnica, o qual possuía um total de 22 (vinte e dois) discentes. Todavia, é necessário destacar que, neste momento, frente as metas propostas, houve apenas a observação do desenvolvimento do projeto em todas as suas etapas, não sendo realizada entrevista alguma com os alunos.

Convém ressaltar que, esta opção deu-se tendo em vista o fato de que seria inviável a observação do funcionamento dos projetos em todas as turmas, por questões de abrangência do estudo, bem como, de tempo e disponibilidade do pesquisador. Ademais, acredita-se ser desnecessário este procedimento, pois a amostra da aplicação do projeto em uma turma, já pode ser considerada suficiente para o alcance das metas estabelecidas; ao possibilitar a visualização, o acompanhamento in loco e a compreensão ampla do desenvolvimento e aplicação de um Projeto Integrador em todos os momentos.

Como os instrumentos de pesquisa direcionam e orientam o processo de coleta de dados, para o alcance dos objetivos deste estudo foram utilizados os seguintes procedimentos; a observação participante, pois, conforme já mencionado houve o acompanhamento efetivo desde a elaboração até a conclusão de um dos projetos integradores; a aplicação de questionários nos docentes da instituição, bem como, a consulta à documentação norteadora do projeto integrador (BIASOLI-ALVES; ROMANELLI, 1998).

Os cursos técnicos da instituição pesquisada contavam, no período da pesquisa, com um total de 60 (sessenta) professores, das mais variadas áreas de atuação e lecionando diferentes disciplinas; sendo que, os questionários ( apêndice 1), contendo 15 perguntas entre fechadas e abertas - foram impressos e distribuídos para todos estes profissionais, solicitando-se sua devolução, devidamente preenchidos, dentro de 15/20 dias. No mesmo período, enviou-se um e_mail aos docentes, reforçando a necessidade de seu preenchimento e prestando maiores esclarecimentos acerca de seus objetivos.

De acordo com o Gráfico 1, é possível observar que $20 \%$ dos professores não responderam as questões, entregando o questionário em branco com a alegação de falta de tempo (8 docentes), alguns demonstraram ainda desinteresse, receio em responder e desmotivação. Porém, $80 \%$ dos docentes (48 educadores) responderam as questões, o que se constitui uma amostra significativa, proporcionando validade ao estudo em questão. 
Gráfico 1: Dados da amostragem

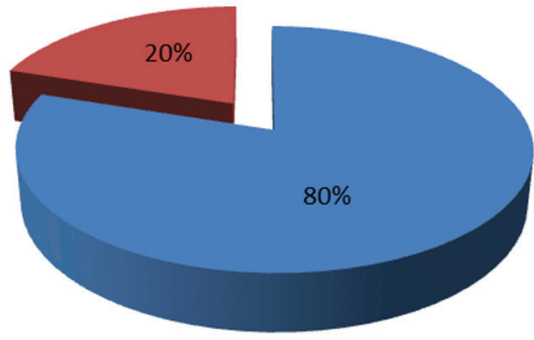

घ Responderam ao questionário @ Não responderam ao questionário

Fonte: Dos autores

Com relação ao tratamento proporcionado aos dados coletados, destacam-se que eles sofreram tanto a análise quantitativa, através da tabulação dos dados coletados nas perguntas fechadas do questionário e organizados estatisticamente em forma de gráficos; como a análise qualitativa, onde buscou-se compreender e analisar a realidade observada no decorrer do processo; bem como as respostas às questões abertas do referido instrumento; com base na literatura de apoio ao estudo.

\section{O REFERENCIAL TEÓRICO}

\subsection{O contexto educacional contemporâneo}

O cenário atual apresenta características diferenciadas de tempos atrás. A globalização e a explosão tecnológica e informacional promoveram transformações em todas as esferas sociais, resultando em implicações variadas sobre a realidade e os sujeitos (CASTELLS, 2002). Assim, o sistema educacional, precisa ter em mente estes aspectos e buscar uma "adequação" ao novo panorama que se descortina, uma vez que métodos e técnicas antigas podem tornar-se cansativos e até mesmo obsoletos, não produzindo os resultados esperados.

O contexto escolar precisa desenvolver currículos integrados, de modo que os conteúdos, ainda que ordenados em disciplinas separadas, sejam trabalhados e abordados de forma unificada, isto é, pelas várias áreas do conhecimento, mantendo uma articulação coerente (GADOTTI, 1997). O objetivo é que o conhecimento construído pelos educandos e mediado pelas ações docentes venha a propiciar a interpretação, análise, compreensão e problematização dos fatos e dos fenômenos componentes da complexa realidade que vivenciam. 
Os currículos escolares, portanto, devem primar pela multidisciplinaridade e pela intersecção de conhecimentos, trabalhando em prol da formação de identidades abertas à pluralidade cultural existente na contemporaneidade, as quais sejam desafiadoras e isentas de preconceitos. A meta é trabalhar sob uma perspectiva de educação para a cidadania e pelo exercício da ética nas relações interpessoais, instigando a crítica às desigualdades sociais e econômicas existentes nas várias esferas da sociedade atual, inclusive, nos contextos educacionais (DEMO, 1994).

É importante destacar que, os posicionamentos éticos e crítico do sujeito, abrangem a assimilação e a reconstrução de conceitos e do conhecimento cultural oriundo do contexto social no qual se encontra inserido. Assim, à escola cabe estimular nos alunos a capacidade de expressão e comunicação de suas ideias, além de levá-los a participar e interpretar as produções culturais, intervindo e construindo realidade, através do uso do pensamento lógico, da criatividade e da análise crítica daquilo que vivenciam. Segundo Veiga (2002), este processo é viabilizado pelas disciplinas que propiciam ao educando o seu desenvolvimento como cidadão crítico e consciente, visando à inserção social, política e compromisso histórico e cultural, além do exercício cotidiano dos seus direitos, deveres, atitudes, condutas, como uma atitude de respeito às diversidades e exercício da democracia.

Neste panorama vivenciado, a interdisciplinaridade assume um papel cada vez mais importante e vital no processo de ensino/aprendizagem, uma vez que visa valorizar os domínios de cada área (VASCONCELLOS, 2002). Deste modo, ela precisa propiciar condições necessárias para coexistência de um diálogo e da articulação efetiva entre as disciplinas, inclusive, entre os aspectos teóricos e práticos, uma vez que este processo interdisciplinar tem a finalidade de estabelecer relações que levem o educando a processar, compreender, pensar, analisar e criticar os diferentes conteúdos, estabelecendo as ligações necessárias entre os campos do conhecimento. Além de permitir-lhe uma construção coerente e lógica das informações disponibilizadas pelas diferentes áreas, desenvolvendo assim, a autonomia, o raciocínio e a capacidade de análise crítica da realidade vivenciada, fazendo-se cumprir o objetivo primordial do processo de aprendizagem.

\subsection{O processo de ensino/aprendizagem}

O processo de ensino/aprendizagem é bastante amplo e complexo, e, por este motivo, vem sendo fonte de estudos desde que se começou a perceber sua importância, além do papel que ele desempenha na vida dos sujeitos, bem como para o desenvolvimento da sociedade. A partir destas considerações, destaca-se que são várias as concepções elaboradas a respeito das questões ligadas ao aprendizado dos seres humanos, porém, este estudo embasa-se nos fundamentos da teoria histórico cultural, desenvolvida por Vygotsky e seus precursores (VYGOTSKY, 1989; ZANELLA, 2004). 
Segundo Dayrel (1996), a referida teoria ganhou força no Brasil no final da década de 1980 , depois que ficou conhecida como sendo uma nova compreensão de educação. As concepções desenvolvidas por ela afirmam que cada ser humano elabora o conhecimento produzido pela humanidade com a ajuda dos outros. Isso significa que a aprendizagem não pode ser desvinculada do ensino e que a elaboração do conhecimento não se constitui como um processo solitário, acontecendo na interação entre pessoas social e culturalmente situadas.

A concepção histórico-cultural considera que todos são capazes de aprender e que as relações estabelecidas são fatores primordiais de apropriação de conhecimento. Esta compreensão de educação traz consigo a responsabilidade ética da escola com a aprendizagem, uma vez que esta se caracteriza como um processo contínuo, o qual promove o desenvolvimento constante do ser humano; ocorre nas relações estabelecidas entre o homem e o mundo e, é sempre medido por outros sujeitos. Deste modo, é pela interação com o meio e com os demais que o indivíduo aprende, transforma-se e se constitui em sujeito (ZANELLA, 2004).

Segundo esta teoria, o conceito de mediação pressupõe a transformação do sujeito e do meio, através da utilização de instrumentos (externos) e signos (internos). O ser humano se relaciona com o conhecimento por meio de instrumentos, objetos externos a ele, através do qual se chega ao significado das coisas (MARTINS, 1997). Também estabelece relações com o conhecimento através de signos, ou seja, dos significados com os quais o ser humano tem a capacidade de lidar, em nível mental, sem recorrer a instrumentos externos, como palavras pensadas e significados numéricos. Nota-se assim que, o ser humano não é capaz de se relacionar de forma direta com o conhecimento, necessitando da mediação.

Frente às exposições tecidas, destaca-se que para esta concepção o desenvolvimento humano não é processado e nem ocorre de modo contínuo e linear, mas sim, através de avanços e de saltos qualitativos. Ao apropriar-se de um conhecimento e de uma forma inédita, o sujeito modifica-se, alterando, concomitantemente, seu contexto. Assim, o fator principal de desenvolvimento baseia-se na apropriação de novas formas, novos significados e signos, enfim, de conhecimentos inéditos pelo sujeito.

Tendo em vista estas considerações, pode-se perceber que o processo de ensino/ aprendizagem caracteriza-se como algo extremamente ativo, onde para haver aprendizado, é preciso que o aluno aja e não apenas receba os conteúdos prontos. Ele precisa reelaborar aquilo que vivenciou, tornando o conteúdo "seu", formando seus próprios conceitos e realizando aquilo que antes alguém precisava fazer por ele (MIZUKAMI, 1986). Percebe-se que esta concepção, a histórico-cultural, permite a compreensão ampla do processo de aprendizagem, o qual, no contexto educacional, encontra-se interligado com o ensino, sendo indissociáveis, pois, para poder dizer que houve ensino é imprescindível que exista aprendizagem. 
A escola contemporânea, neste sentido, deve buscar contemplar os aspectos que envolvem o processo de ensino/aprendizagem, organizando suas grades curriculares e suas estratégias de ensino de forma que o conhecimento seja o mais abrangente possível, ou seja, evitando a segregação entre os diversos saberes, bem como, a dissociação entre a teoria e a prática. Destarte, com base nestas considerações, é que o SENAI/SC, desenvolveu o instrumento de ensino do Projeto Integrador.

\subsection{0 projeto integrador como ferramenta didático/pedagógica}

Tendo em vista os aspectos que compreendem e englobam o contexto educacional contemporâneo, e, consequentemente, o processo de ensino/ aprendizagem, urge a necessidade de constante aperfeiçoamento, melhorias e ajustes das práticas e dos instrumentos pedagógicos no decorrer do processo educacional. Ademais, as exigências das empresas sobre a qualificação dos profissionais estão cada vez maiores. Assim sendo, o SENAI/SC, começou a fazer uso, a partir do ano de 2007, de uma ferramenta didáticopedagógica denominada de Projeto Integrador.

O Projeto Integrador em questão embasa-se nos documentos norteadores do processo educacional do SENAI/SC - que encontram-se disponíveis na Intranet (Desenho curricular e Perfil Profissional dos Cursos) - e no Manual da Educação (MED) - os quais visam nortear, estabelecer parâmetros e consolidar a educação por competências, qual seja, a concepção pedagógica preconizada pelo ensino da rede SENAI/SC. Além disso, segue os preceitos estabelecidos pelo Projeto Pedagógico de Curso e pelo Projeto Político Pedagógico das Unidades. Estes preconizam o desenvolvimento dos conhecimentos, habilidades e atitudes dos discentes, visando prepará-los para a indústria, mas também promover seu desenvolvimento pessoal e profissional.

O Projeto Integrador justifica-se, tendo em vista o fato de que tende a proporcionar uma maior integração entre os professores das várias áreas de conhecimento e os diversos conteúdos a serem desenvolvidos no decorrer do período letivo, promovendo assim, a multidisciplinaridade. Além disso, serve como auxilio para o desenvolvimento das competências, habilidades e atitudes, ao relacionar a teoria com a prática, fortificando o aprendizado dos discentes.

Frente suas possibilidades de aplicabilidade prática, o referido projeto serve para uma contextualização da teoria, ao proporcionar a efetiva vivência dos conteúdos. Além disso, estimula o enfrentamento de situações e problemas, uma vez que é elaborado, de forma conjunta, por todos os professores que irão lecionar em determinado semestre, os quais escolhem um tema e desenvolvem o objetivo geral do Projeto Integrador, que deve ser passível de alcance por todos. Posteriormente, cabe a cada docente analisar e elencar objetivos específicos relativos aos conteúdos ministrados em sua disciplina; bem como, as competências, habilidades e atitudes que precisam ser desenvolvidas; formando um todo complexo e organizado. 
Ao concluir a elaboração teórica do Projeto Integrador de determinado curso e turma, cabe aos docentes de cada disciplina estabelecer estratégias e um cronograma único, para o alcance dos objetivos propostos, visando, ao término do semestre ou ano letivo, que os resultados propostos sejam realmente obtidos. Assim, no decorrer do período, os conteúdos do Projeto Integrador devem ser trabalhados concomitantemente com as demais temáticas previstas pelo Plano de Ensino, ou seja, os professores precisam interligar os conhecimentos, unificando, inclusive, as várias áreas de conhecimento.

É importante destacar que, o projeto em questão deve ser desenvolvido, conforme pontuado acima, de forma simultânea às aulas, ou seja, não há uma carga horária diferenciada para sua implantação. Tendo em vista estes aspectos, ele precisa ser elaborado de modo que seja possível esta articulação entre as várias áreas do conhecimento - muitas vezes bastante distintas -, com os conteúdos previamente estabelecidos pela ementa escolar. Deste modo, esta pesquisa buscou verificar como esse processo ocorre na prática, visando identificar seus pontos positivos e os passíveis de melhorias, bem como, as concepções que os docentes têm a seu respeito, a fim de propor melhorias, para que realmente os objetivos sejam alcançados, chegando às considerações apresentadas a seguir.

\section{OS RESULTADOS OBTIDOS}

A partir dos questionários respondidos e das observações realizadas em sala de aula, pôde-se chegar a considerações fundamentais acerca das concepções que os docentes têm a respeito do Projeto Integrador e de seu papel no processo de ensino/ aprendizagem. Considera-se a que amostra utilizada foi relevante ao alcance das metas e as análises possibilitaram respostas aos objetivos. Todavia, optou-se pela descrição dos resultados, inserindo no decorrer do texto, apenas os gráficos mais significativos, a título de ilustração e maior visibilidade.

Tendo em vista estes aspectos, o gráfico 2, demonstra a realidade dos professores participantes da pesquisa em relação ao "tempo de casa", isto é, quanto ao tempo em que atuam na instituição pesquisada. Assim, pode-se observar que a maioria trabalha há mais de (5) cinco anos na referida unidade; $43 \%$, estão há mais de um ano na instituição e somente $10 \%$ possuem menos de um ano de casa. 

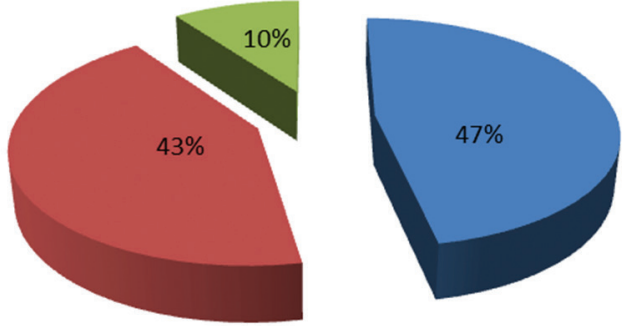

E Há mais de 5 anos na instituição

- Há mais de 1 anos na instituição

Menos de 1 ano na instituição

Fonte: Dos autores

Esses dados são relevantes, frente o fato de que no início de cada semestre, os educadores (tanto recém admitidos, quanto os mais antigos) passam por cursos de aperfeiçoamento, os quais propiciam a troca de experiências e, certamente, auxiliam na compreensão das diretrizes de ensino preconizadas pelo SENAI/SC, o que tende a facilitar o desenvolvimento e aplicação do Projeto Integrador. Mesmo com a participação em eventos de capacitação, entretanto, os professores destacam que ainda há necessidade de maiores esclarecimentos e disponibilização de treinamentos exclusivos sobre o Projeto Integrador e também referente ao trabalho inter e multidisciplinar.

Alguns educadores apontaram, inclusive, ter dificuldades em aplicar o Projeto Integrador, por falta de conhecimento da área de atuação específica do curso, isto é, professores de Matemática e Língua Portuguesa, por exemplo - que muitas vezes não tem ciência sobre as áreas da mecânica, elétrica, computação, entre outros -; encontram dificuldades em atrelar suas disciplinas às demais componentes de determinado Projeto Integrador. Este fato reforça a necessidade de capacitações frequentes, além de encontro entre os docentes das várias áreas, visando à troca de experiências e conhecimentos.

Os índices obtidos na questão referente ao conhecimento acerca do Projeto Integrador reforçam estas concepções, pois, conforme mostra o Gráfico 3, identifica-se que grande parcela dos docentes, $85 \%$ tem conhecimento, sabe do que se trata e como funciona este instrumento didático-pedagógico - sendo que destes, $57 \%$ possuem conhecimentos razoáveis e $28 \%$ que conhecem bastante o Projeto. Entretanto, $15 \%$ dos educadores assinalaram ter pouquíssimos conhecimentos sobre esta ferramenta, apontando a necessidade de maiores esclarecimentos. Destaca-se que, foi possível observar nos questionários, que este grupo específico (15\%) coincide com a parcela de professores que está há pouco tempo na instituição, não tendo, consequentemente, obtido treinamentos sobre o assunto. 


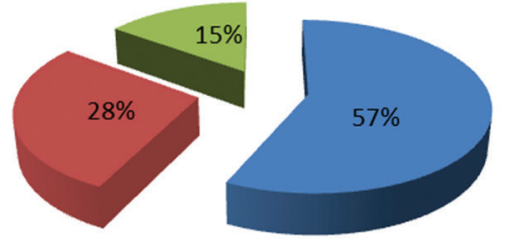

- Bastante conhecimento sobre o projeto

— Conhecimento razoável sobre o projeto

n Com pouquíssimo conhecimento.

Fonte: Dos autores

Sobre estes aspectos, pode-se verificar que a respeito da oferta de treinamentos para elaboração e desenvolvimento do Projeto Integrador, $28 \%$ dos professores acreditam ter recebido treinamento razoavelmente adequado para o processo em sua amplitude, ou seja, para a criação e aplicação de um Projeto Integrador. No entanto, $68 \%$ crê que seu conhecimento é suficiente apenas à implantação do Projeto Integrador, não para sua elaboração e $4 \%$ dos educadores vê seu saber como suficiente apenas para elaborá-lo.

Tais escores estão ligados ao perfil dos profissionais de coordenação, onde os coordenadores de curso, dos quais alguns também exercem as funções de docentes, recebem treinamentos diferenciados e depois servem como multiplicadores. Deste modo, a tendência é que estes profissionais tenham conhecimentos distintos e mais profundos sobre o assunto, referindo-se - conforme análise dos questionários - aos $28 \%$ que conhecem o processo global e aos $4 \%$ que encontram-se preparados apenas para sua elaboração, pois têm menos experiência em sala de aula, desenvolvendo funções burocráticas e ligadas à coordenação.

Outro ponto que merece destaque é o fato de que a unidade do SENAI/SC de Rio do Sul, conta com $62 \%$ de seu quadro de colaboradores sob o regime de horistas, ou seja, são docentes que recebem por hora e não são exclusivos da instituição, pois, trabalham em outras escolas e empresas. Esta situação faz com que, muitas vezes, eles não consigam comparecer aos treinamentos disponibilizados, por mais que sejam incentivados e/ou convocados; o que restringe seus conhecimentos acerca do Projeto Integrador.

Sobre estas considerações, destaca-se que foi possível verificar nas observações realizadas in loco, que o treinamento dos professores e o conhecimento acerca do Projeto Integrador são pontos bastante importantes e necessários ao sucesso desta ferramenta. Assim, pode-se averiguar que as capacitações são um ponto passível de melhoria e aperfeiçoamento, visando proporcionar maior segurança aos docentes no momento da aplicação do Projeto Integrador . Uma estratégia de melhorar e alterar esta 
situação, consistem em disponibilizar mais cursos a este respeito no decorrer do ano letivo. Deste modo, os educadores que não conseguem participar em determinada data, têm a possibilidade de realizá-los em outros momentos.

Conforme mostra o gráfico 4, no que se refere à participação na elaboração do Projeto Integrador destaca-se que $18 \%$ apenas elabora o projeto e não aplica-o, na maioria coordenadores de curso e $30 \%$ tem participação total no processo. Já $42 \%$ afirmam raramente passar por essa etapa, ressaltando que são responsáveis apenas por adequar seus objetivos a algo definido a priori pela equipe de professores e/ou coordenação do curso e alcançá-los. Quando questionados a respeito dos motivos deste fato, uns afirmaram não ter tempo para ajudar; alguns por serem horistas e exercerem outras atividades profissionais e outros complementaram afirmando que isto se encontra ligado às várias atividades que desempenham na própria instituição. Um fato curioso nas respostas obtidas neste questionamento é que $10 \%$ dos docentes não assinalaram nenhuma alternativa, talvez por não aplicarem o Projeto Integrador e terem receio de afirmar isto (dados que vem ao encontro das respostas obtidas no Gráfico 5).

Entre os educadores questionados, alguns ressalvaram ainda que não costumam ajudar na elaboração do Projeto Integrador, porque a disciplina que lecionam não tem uma participação tão ativa no processo, ou seja, por serem professores das chamadas "disciplinas transversais", comuns à grande maioria dos cursos, mas sem ênfase específica, como é o caso de Comunicação Oral e Escrita; Fundamentos da Matemática; e Gestão de Pessoas. Assim, a falta de conhecimento técnico, o que dificulta sua participação. A este respeito um dos docentes escreveu que "Como a minha é uma disciplina transversal, às vezes fica difícil participar, tanto na elaboração como na aplicação. ${ }^{3 \text { " }}$

Gráfico 4: Participação na elaboração do instrumento

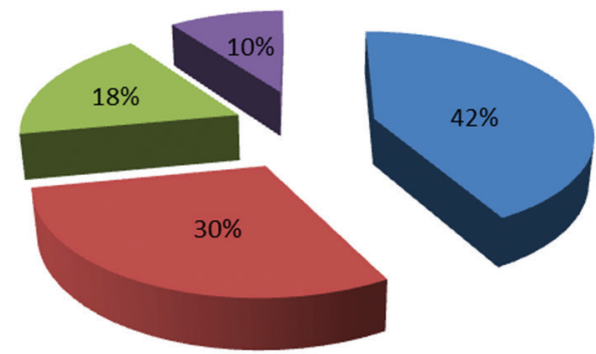

- Somente aplicam e não elaboram — Elaboram e aplicam

匹 Só elaboram e não aplicam

não responderam

Fonte: Dos autores

3 Convém destacar que todas as frases escritas pelos docentes e copiadas na íntegra do questionário estão entre aspas e em itálico, a fim de diferenciar dos autores que embasam e fundamentam este estudo. 
No gráfico 5, observa-se à aplicação efetiva do Projeto Integrador, no entanto, mais da metade dos professores, (61\%), afirmam que costumam desenvolvê-lo em sua disciplina. Entretanto, ao unificar os que assinalaram que não dão conta de aplicá-lo (29\%) com os que raramente conseguem sua aplicação (10\%), obtém-se um total de $39 \%$; evento que merece atenção, ao caracterizar-se como um percentual relativamente elevado. Assim, buscou-se averiguar também os motivos desta impossibilidade e a maioria - $51 \%$ dos docentes - afirmou que a carga horária é insuficiente para seu desenvolvimento eficaz, tendo em vista o fato de que precisam "dar conta do restante dos conteúdos".

Gráfico 5: Aplicação do projeto

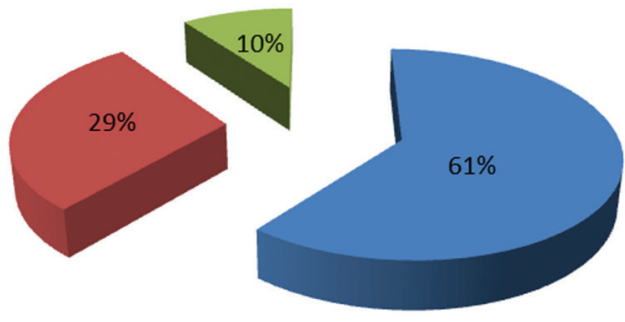

- Desenvolvem o projeto na disciplina

- Não dão conta de aplicar

- Raramente conseguem aplicar

Fonte: Dos autores

Outro aspecto que inviabiliza o desenvolvimento do Projeto Integrador - conforme apontado por $15 \%$ dos docentes - refere-se especificamente à "falta de conhecimentos técnicos sobre a área". A respeito destas afirmações, destaca-se ainda que $12 \%$ dos professores assinalaram ter dificuldades em trabalhar de forma interdisciplinar. Estes índices servem de indicadores acerca da necessidade de treinamentos nesta área específica, ou seja, a interdisciplinaridade; além da disponibilidade de uma carga horária maior para o desenvolvimento do Projeto Integrador.

Apesar dos escores obtidos sobre o desenvolvimento do Projeto Integrador, dos 61\% dos docentes que costumam implantá-lo, a maioria (70\%) afirma que sempre ou quase sempre conseguem alcançar os objetivos propostos. Estes índices vêm corroborar com sua importância e com o fato de que, conforme pode ser observado, busca-se um "alinhamento" entre teoria e prática, ao elaborar projetos passíveis de aplicação. Os $30 \%$ que apontaram que raramente ou nunca alcançam as metas propostas, justificam esta situação a partir, novamente, da falta de tempo e depois se referem aos alunos, assinalando que estes carecem de mais empenho, colaboração e conhecimentos para chegar aos objetivos propostos. 
Dentre os professores que desenvolvem efetivamente o Projeto Integrador (61\% dos 48 docentes participantes da pesquisa), um percentual de $12 \%$ dos educadores afirma ter dificuldades em comunicar-se com os demais docentes da turma, isto é, no decorrer do cotidiano de trabalho não conseguem conversar com os colegas e esclarecer determinados aspectos referentes ao desenvolvimento do Projeto Integrador. Este fato indica a necessidade de reuniões frequentes no decorrer do semestre, para verificar 0 andamento do Projeto Integrador em questão, bem como, para tirar dúvidas e elencar sugestões, visando alcançar seu sucesso.

As respostas dos professores sobre o que poderia facilitar a aplicação do Projeto Integrador e o alcance dos objetivos vêm corroborar com os dados obtidos até o momento, uma vez que 31\% apontam, novamente, a necessidade de maior disponibilidade de tempo e de carga horária específica para o Projeto Integrador, o que demonstra ser este um fato realmente carente de atenção e passível de melhorias. Além disso, $21 \%$ destacam a necessidade de treinamentos e cursos de capacitação, fato já emergente em questões anteriores, e $19 \%$ assinalam a necessidade de maior conscientização dos alunos sobre a importância do Projeto Integrador, o que indica ser preciso trabalhar sobre o Projeto Integrador, não apenas com os docentes, mas também com o corpo discente da instituição.

Com relação a este aspecto convém lembrar que segundo Vygotsky (1989), para o processo de aprendizagem ter resultados efetivos é preciso que este seja ativo, isto é, para o aluno aprender ele deve, inicialmente, desejar este conhecimento, e para isso ele precisa ter motivos, ver a importância do aprendizado adquirido e é papel dos professores demonstrarem esses motivos, apontando tanto aspectos do ponto de vista racional como emocional.

Entre os pontos positivos do Projeto Integrador apontados pelos educadores, $27 \%$ destacam a ligação efetiva entre teoria e prática, o que demonstra que ele realmente tende a proporcionar esta intersecção, uma vez que, nas palavras dos docentes, ele "demonstra a realidade entre a teoria e prática" e ainda "Visto que o projeto desde abraçado pelo aluno, pela equipe e ou turma contribui com exemplos reais do dia a dia, desde concepção, desenvolvimento e execução do mesmo". Os professores destacam também que são múltiplos os benefícios desta ferramenta, pois permite a interdisciplinaridade, incentiva o trabalho em equipe e o desenvolvimento da criatividade, além disso, "com o Projeto Integrador os alunos ampliam sua visão de conhecimento, pois com a junção das disciplinas eles aprendem muito mais".

Tendo em vista as transformações em todos os âmbitos sociais, bem como, a inserção efetiva das tecnologias de informação nos lares dos estudantes, o cenário educacional contemporâneo carece, cada vez mais, de estratégias e instrumentos de ensino estimulantes, motivadores e diferenciados, a fim de enfrentar a "competitividade" que travam cotidianamente com a grande quantidade de aparatos tecnológicos com os quais os alunos relacionam-se (DAYREL, 1996). No contexto atual, o acesso às informações é muito rápido e encontram-se bastante acessível, assim, os educandos deparam-se com uma infinidade de opções de aprendizado, muitas vezes, infinitamente mais atraentes 
que a sala de aula, o que faz com que os professores precisem ser cada vez mais criativos e fato que reforça o papel do Projeto Integrador, ao buscar unificar teoria e prática.

Tendo em vista estas considerações, destaca-se que $80 \%$ dos docentes pesquisados afirmam que o custo de tempo e de recursos financeiros investidos no Projeto Integrador são plenamente justificados e válidos, principalmente, tendo em vista os resultados obtidos, pois, "Se as etapas, os objetivos e a comunicação entre as áreas envolvidas funcionarem bem, os discentes haverá sentido e haverá bons aprendizados, além de se ter todo equipamento e materiais necessários". Ademais, $71 \%$ dos educadores afirmam que o Projeto Integrador colabora imensamente com o aprendizado e apenas $4 \%$ não concebem que ele traz grandes contribuições aos discentes. Talvez estas concepções estejam ligadas ao fato de que, conforme um dos professores aponta, "[...] nem todos os alunos apresentam o devido comprometimento" e outro destacou ainda que "o aprendizado é proporcional ao comprometimento do aluno com o Projeto Integrador.

Estas palavras ilustram sobremaneira a "essência" do Projeto Integrador, pois, através da análise quantitativa e qualitativa demonstrada até o momento, pôde-se perceber que, para a maioria dos docentes que atuam nos cursos técnicos do SENAI/SC da unidade de Rio do Sul, ele constituiu-se como uma ferramenta de grande valia, porém como todo instrumento didático necessita de clareza nos objetivos, comunicação efetiva entre as partes, bem como o amplo engajamento de todos os envolvidos no processo.

Findo este processo, pode-se perceber que o Projeto Integrador além de ser uma forma de avaliação dinâmica e eficaz, é avaliado pela maioria dos docentes como sendo um instrumento de grande valia e importância para o aprendizado dos alunos, uma vez que proporciona o desenvolvimento efetivo e global dos conhecimentos, habilidades e atitudes; ao unificar, tanto aspectos teóricos quanto práticos, dos saberes das diversas áreas de conhecimento. Outro ponto destacado foi o estímulo ao trabalho em equipe, à criatividade e à multidisciplinaridade. Muitos docentes, porém, apontaram a falta de carga horária específica para o desenvolvimento do Projeto Integrador e de mais treinamento, como sendo aspectos negativos à sua realização eficaz, além da necessidade de maior empenho e envolvimento por parte de determinados alunos. Assim, o referido Projeto Integrador apesar de possuir pontos a serem aperfeiçoados, caracteriza-se como uma ferramenta fundamental ao processo de ensino/aprendizagem.

Apesar dos pontos carentes de melhorias, de modo geral a maioria dos professores apontou que o Projeto Integrador constitui-se como uma ferramenta fundamental e de grande auxílio ao aprendizado dos discentes, fato que pode ser percebido também a partir dos próprios resultados dos Projetos observados - apesar de ater-se mais especificamente a um dos Projetos, convém destacar que, pela prática docente o pesquisador teve a possibilidade de vivenciar e observar o resultado de vários Projetos Integradores, dos diversos cursos existentes na instituição, uma vez que eles são socializados sempre que possível, principalmente em um evento denominado "SENAI Casa Aberta".- os quais tornam as palavras desnecessárias. Entretanto, os professores apontam que entre as contribuições deste instrumento está, principalmente, a ligação efetiva entre a teoria e prática, pois, com a participação no Projeto Integrador "os alunos conseguem assimilar com muita facilidade os conteúdos abordados em sala". 


\section{CONSIDERAÇÕES FINAIS}

Por meio da pesquisa realizada, cujo objetivo foi de analisar papel do Projeto Integrador no processo de ensino/aprendizagem dos alunos, observa-se que a maioria dos professores que atuam nos cursos técnicos do SENAI/SC, em Rio do Sul,e, trabalham há mais de um ano e seis meses na instituição. Esta situação constitui-se como um fator positivo, uma vez que a cada início de semestre são realizados treinamentos e cursos de capacitação, sendo que, com frequência, no decorrer do semestre, determinados docentes também são convidados a participarem de momentos de qualificação profissional, o que irá facilitar sobremaneira o conhecimento e a aplicação do Projeto Integrador.

Os índices referentes ao conhecimento a respeito do Projeto Integrador vêm corroborar com estas afirmações, uma vez que a maior parte dos professores afirma possuir conhecimentos acerca desta ferramenta de ensino/aprendizagem, o que, sem dúvida, constitui-se como fundamental, pois para que os objetivos sejam atingidos e para que este instrumento realmente proporcione os resultados almejados, é preciso que os docentes saibam como elaborá-lo e utilizá-lo de forma adequada, e assim ter, mais segurança e propriedade sobre o assunto, fato perceptível aos alunos.

A partir destes apontamentos, faz-se necessário destacar que pela pesquisa foi possível concluir também que um ponto passível de melhorias, encontra-se relacionado ao fato de que não há uma carga horária especificamente definida para a aplicação do Projeto Integrador. Para sua elaboração é disponibilizado um momento exclusivo, geralmente no início de cada semestre, porém, ele deve ser aplicado no decorrer das aulas. Todo Projeto Integrador elaborado busca contemplar os conteúdos específicos de cada período, porém, às vezes, ele exige conhecimentos diferenciados daquilo que é proposto, o que leva os docentes a terem maior habilidade para lidar com essa situação e conseguir alcançar tanto as metas do Projeto Integrador, quanto às de sua disciplina.

Cabe aqui, a proposta de análises por parte da referida instituição, sobre a possibilidade de realizar treinamentos específicos a respeito do Projeto Integrador e também referentes ao trabalho interdisciplinar, bem como, de disponibilizar uma carga horária dentro de cada curso, especificamente para o trabalho do Projeto Integrador e para momentos de troca de informações e experiências entre os educadores, inclusive, sobre como incentivar e motivar os alunos a participarem e aderirem à ideia do Projeto Integrador. Estas sugestões derivam do fato de que tanto a necessidade de reuniões no decorrer do período, quanto a falta de comprometimento de determinados alunos, pode constituir-se como aspectos que dificultam o alcance dos objetivos propostos pelo Projeto Integrador.

Além de desempenhar um papel fundamental para união da teoria com as questões práticas, a pesquisa aponta que o Projeto Integrador estimula o trabalho em equipe, o desenvolvimento da criatividade, da liderança, da comunicação e expressão (pois cada projeto precisa ser apresentado), do pensamento crítico e analítico, bem como, da multi e interdisciplinaridade. Além disso, ele constitui-se como um instrumento de avaliação 
bastante útil e abrangente, ao proporcionar o acompanhamento do aluno em todas as etapas do processo, verificando e analisando tanto seus conhecimentos teóricos, como sua habilidade de aplicá-los de forma concreta e objetiva.

Os resultados obtidos com a pesquisa, portanto, satisfazem os requisitos de objetividade e pequena dimensão que pretendia atingir, pois, para maior compreensão deste instrumento, seria importante conhecer as concepções que os alunos têm a respeito do Projeto Integrador, a fim de verificar, como eles concebem esta ferramenta e se conseguem perceber o desenvolvimento de seu aprendizado através desta mediação. Porém, frente às delimitações de tempo e espaço fica esta sugestão e também a de, posteriormente, comparar as respostas obtidas na pesquisa efetuada junto aos professores, com aquilo que os discentes apontarem. Enfim, é importante valorizar e analisar os instrumentos e métodos de ensino, uma vez que tudo que possa vir a contribuir para melhorias no processo de ensino/aprendizagem deve ser analisado e valorizado, tendo em vista sua importância tanto para o sujeito, como para a sociedade de modo geral.

\title{
INTEGRATOR PROJECT: A TOOL FOR TEACHING AND LEARNING IN TECHNICAL COURSES
}

\begin{abstract}
Faced with the characteristics of the contemporary scene, the educational context must often evaluate its teaching methods in order to adapt them to social demands. Thus, SENAI-SC established in its curriculum, the development of "Integrator Projects". This didactic-pedagogic tool includes planning and implementing of a project that includes the various disciplines of the semester, promoting multidisciplinarity. The purpose of this activity is the establishment of relationships between theory and practice, aiming at problem solving and application of acquired knowledge in real situations. Starting from these considerations, this article aims to analyze the role of the Integrator Project in the teaching / learning process of students of technical courses SENAI-SC, of the city of Rio do Sul, according to the conceptions of teachers. For this, a survey was conducted in documentary materials that orient this tool, followed by observation and monitoring of the implementation of the Project in a class. Afterwards, a questionnaire was applied, in conjunction with the teachers of technical courses in order to obtain data regarding their conceptions. Through observation and by quantitative and qualitative analysis of the responses, we can see that most teachers conceives the Integrator Project as a tool of paramount importance in the teaching / learning process of, because in addition to
\end{abstract}


increase the knowledge of the student through the link between theory and practice, serves to encourage interdisciplinarity, stimulates the development of creativity and promotes team work for both the students and the lecturers.

Keywords: Education. Project Integrator. Learning. Teachers.

\section{REFERÊNCIAS}

BIASOLI-ALVES, Zélia M. M.; ROMANELLI, Geraldo. Diálogos Metodológicos sobre prática de pesquisa. Ribeirão Preto: Legis Summa, 1998.

CASTELLS, Manuel. A era da informação: economia, sociedade e cultura. 3.ed. São Paulo: Paz e Terra, 2002.

DAYREL, Juarez Tarcisio (Org). Múltiplos Olhares sobre educação e cultura. Belo Horizonte: Editora da UFMG, 1996.

, Juarez Tarcísio. A educação do aluno trabalhador. Educação em Revista (UFMG), Belo Horizonte, v. 15, n. 2, p. 21-29, 1992.

DEMO, Pedro. Educação e qualidade. Campinas: Papirus, 1994.

GADOTTI, Moacir. Projeto Político Pedagógico da escola: fundamentos para sua realização. São Paulo: Cortez, 1997.

GIL, Antonio Carlos. Métodos e Técnicas de Pesquisa Social. 5ạ Ed. São Paulo: Atlas,1999.

MARTINS, João Carlos. Vygotsky e o Papel das Interações Sociais na Sala de Aula: Reconhecer e Desvendar o Mundo. Idéias. São Paulo: FDE, no 28, p. 111-122, 1997.

MIZUKAMI, Maria da Graça Nicoletti. Ensino: as abordagens do processo. São Paulo: EPU, 1986.

RICHARDSON, Roberto Jarry. Pesquisa social: Métodos e técnicas. 3.ed. São Paulo: Atlas,1999.

SERVIÇO NACIONAL DE APRENDIZAGEM INDUSTRIAL. Departamento Regional de Santa Catarina. Perfil profissional eletrotécnica. Florianópolis, 2008. 21 p. Disponível em: <https://www.sc.senai.br/admin/documentos/20081003162458_CTEletrotecnica. PDF>. Acesso em: 3 abr. 2013. 
VASCONCELLOS, Celso dos Santos. Coordenação do trabalho pedagógico: do projeto político pedagógico ao cotidiano da sala de aula. São Paulo: Libertad, 2002.

VEIGA, Ilma Passos Alencastro. Projeto político-pedagógico da escola: uma construção coletiva. In: (org.) Projeto político-pedagógico da escola: uma construção possível. 15. ed. Campinas, SP: Papirus, 2002. p. 11-35. (Col. Magistério: Formação e Trabalho Pedagógico).

VYGOTSKY, Levi S. Pensamento e linguagem. São Paulo: Martins Fontes, 1989.

ZANELLA, Andrea Vieira. Atividade, Significação e Constituição do Sujeito: Considerações à Luz da Psicologia Histórico-Cultural. Psicologia em Estudo, 9, 127-135, 2004.

\section{SOBRE OS AUTORES}

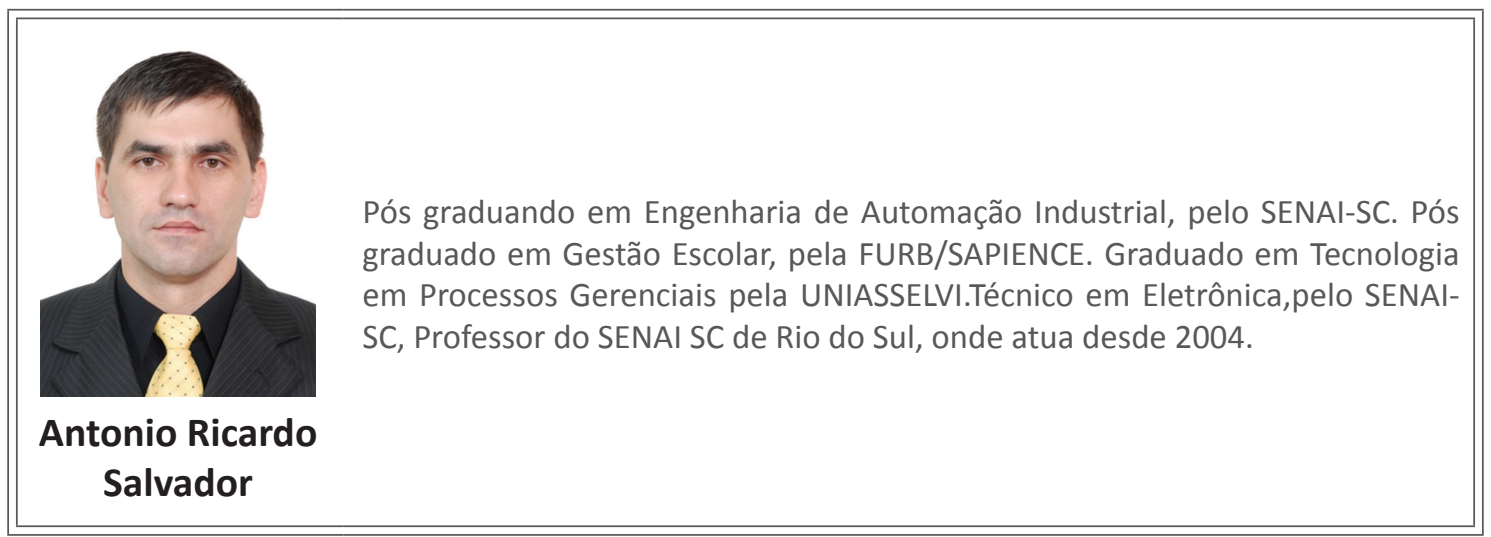

Mestre em Psicologia pela UFSC. Graduada em Psicologia pela UNIDAVI.
Docente do SENAI SC de Rio do Sul desde fevereiro de 2006, atuando nos
cursos técnicos, superiores e de qualificação. Psicóloga Organizacional desde
2005.




\section{APÊNDICES}

\section{QUESTIONÁRIO}

1) TEMPO EM QUE ATUA NA INSTITUIÇÃO:

2) DISCIPLINA (s) QUE LECIONA:

3) QUAL SEU CONHECIMENTO ACERCA DO PROJETO INTEGRADOR?

( ) Tenho total conhecimento acerca do projeto.

( ) Possuo bastante conhecimento sobre o projeto.

( ) Tenho conhecimentos razoáveis sobre projeto.

( ) Sei pouquíssima coisa a respeito deste projeto.

( ) Não sei do que se trata.

Obs:

4) VOCE RECEBEU ALGUM TREINAMENTO ESPECÍFICO A RESPEITO DA ELABORAÇÃO E APLICAÇÃO DO PROJETO INTEGRADOR?

( ) Recebi treinamento que considero amplo e suficiente à elaboração e aplicação do projeto.

( ) Recebi treinamento que considero razoavelmente adequado à elaboração e aplicação do projeto.

( ) Recebi treinamento, mas considero suficiente apenas à elaboração do projeto.

( ) Recebi treinamento, mas considero suficiente apenas à aplicação do projeto.

( ) Recebi treinamento, mas considero insuficiente à elaboração e aplicação do projeto.

( ) Não recebi treinamento algum.

Obs: 
5) VOCE COSTUMA PARTICIPAR DA ELABORAÇÃO DO PROJETO INTEGRADOR?

( ) Sempre

( ) Quase sempre

( ) Raramente

( ) Nunca

Obs:

6) CASO NÃO COSTUME PARTICIPAR DA ELABORAÇÃO DO PROJETO INTEGRADOR ASSINALE OS POSSÍVEIS MOTIVOS:

( ) Falta de tempo para ajudar a elaborá-lo.

( ) Falta de interesse em auxiliar em sua elaboração.

( ) Não tenho conhecimentos necessários para auxiliar em sua elaboração.

( ) Não sou convidado a participar do processo de elaboração do projeto.

( ) A disciplina que leciono não tem participação ativa no projeto, assim, não costumo auxiliar muito.

( ) Outros

7) VOCÊ COSTUMA APLICAR EFETIVAMENTE O PROJETO INTEGRADOR EM SUA DISCIPLINA?
( ) Sempre

( ) Quase sempre

( ) Raramente

( ) Nunca

Obs: 
8) DE QUE FORMA VOCÊ CONSEGUE APLICAR O PROJETO INTEGRADOR EM SUA DISCIPLINA?

( ) Consigo aplicá-lo facilmente.

( ) Consigo aplicar com um pouco de dificuldade.

( ) Consigo aplicá-lo com muitas dificuldades.

( ) Não consigo aplicar.

Obs:

9) CASO NÃO CONSIGA APLICAR FACILMENTE O PROJETO INTEGRADOR EM SUA DISCIPLINA, ASSINALE OS PRINCIPAIS MOTIVOS QUE DIFICULTAM SUA APLICAÇÃO:

( ) Carga horária insuficiente para sua aplicação.

( ) Conteúdo programático excessivo.

( ) Falta de interesse e empenho por parte dos alunos.

( ) Dificuldades em trabalhar de forma interdisciplinar.

( ) Falta de interesse por parte do docente.

( ) Falta de conhecimento sobre sua aplicação.

( ) Recursos didático-pedagógicos insuficientes.

( ) Dificuldades em estabelecer ligações entre a disciplina que leciona e as demais.

( ) Dificuldades em acreditar na relevância e na eficácia do referido projeto.

( ) Outros 
10) EM SUA DISCIPLINA, VOCÊ CONSEGUE EFETIVAMENTE ALCANÇAR OS OBJETIVOS PROPOSTOS PELO PROJETO INTEGRADOR?
( ) Sempre
( ) Quase sempre
( ) Raramente
( ) Nunca

Obs:

11) ASSINALE OS MOTIVOS QUE DIFICULTAM O ALCANCE DOS OBJETIVOS DO PROJETO INTEGRADOR:

( ) Falta de interesse, colaboração e empenho por parte dos alunos.

( ) Falta de incentivo e apoio da coordenação pedagógica do curso.

( ) Escassez de recursos didático-pedagógicos.

( ) Os objetivos difíceis de serem alcançados.

( ) Falta de conhecimento e habilidades por parte dos alunos.

( ) Dificuldades em estabelecer ligações entre o conteúdo teórico e prático.

( ) Falta de tempo para realizar o projeto a contento.

( ) Dificuldades em inserir o projeto no conteúdo programático da disciplina.

( ) Dificuldades de comunicação com os demais docentes.

( ) Outros 
12) EM SUA OPINIÃO, O QUE PODERIA FACILITAR A APLICAÇÃO DO PROJETO INTEGRADOR E O ALCANCE DOS OBJETIVOS PROPOSTOS?

( ) Investimentos em treinamento e capacitação dos docentes.

( ) Maior disponibilidade de tempo e carga horária para aplicação do projeto.

( ) Realização de reuniões periódicas para verificação de seu andamento.

( ) Mais incentivo e apoio por parte da coordenação pedagógica do curso.

( ) Maior conscientização dos alunos a respeito da importância do projeto.

( ) Maiores investimentos em recursos didático-pedagógicos.

( ) Outros

13) QUAIS OS PONTOS POSITIVOS DO PROJETO INTEGRADOR?

( ) Proporciona maior união entre teoria e prática.

( ) Ampliação do conhecimento dos alunos.

( ) Estimulo à interdisciplinaridade.

( ) Incentivo ao trabalho em equipe.

( ) Desenvolvimento da criatividade.

( ) Incentivo à pesquisa.

( ) Amplia o desenvolvimento de competências e habilidades.

( ) Outros

14) EM SUA OPINIÃO, O PROJETO INTEGRADOR CONTRIBUI PARA O APRENDIZADO DOS ALUNOS.

( ) Contribui imensamente.

( ) Traz uma contribuição razoável.

( ) Acarreta pouquíssimas contribuições.

( ) Não contribui.

Justifique sua resposta: 
15) EM RELAÇÃO AO APRENDIZADO DOS ALUNOS, NO QUE SE REFERE AO CUSTO/ BENEFÍCIO DA APLICAÇÃO DO PROJETO INTEGRADOR, VOCÊ CONSIDERA QUE:

( ) O custo, tanto financeiro quanto de tempo e empenho, se justifica, pois o aprendizado dos alunos é significativo e mais importante.

( ) O custo, tanto financeiro quanto de tempo e empenho, não se justifica totalmente frente às contribuições reduzidas que ele traz aos alunos.

( ) O custo do projeto deve ser reduzido ao máximo, uma vez que seus resultados não são significativos.

( ) Tendo em vista os resultados significativos que traz ao aprendizado dos alunos, o custo do projeto se justifica totalmente e poderia, inclusive, ser aumentado.

( ) Tendo em vista os resultados reduzidos que traz, o custo do projeto não se justifica e o torna inviável, portanto, deve ser descontinuado.

Obs: 


\section{ANEXOS}

PLANEJAMENTO DO PROJETO INTEGRADOR CURSO TÉCNICO EM ELETROTÉCNICA

Rio do Sul, 2010

\begin{tabular}{|c|c|c|}
\hline & & ETAPAS DE PLANEJAMENTO DO PROJETO INTEGRADOR \\
\hline Curso: & \multicolumn{2}{|c|}{ Técnico em Eletrotécnica } \\
\hline \multicolumn{3}{|l|}{ Coordenadora: } \\
\hline \multicolumn{3}{|c|}{ Etapa 1. Definição do(s) Projeto(s) } \\
\hline \multicolumn{3}{|c|}{ 1. EQUIPE DOCENTE RESPONSÁVEL PELA ETAPA: } \\
\hline \multicolumn{3}{|l|}{ Coordenador: } \\
\hline \multicolumn{3}{|l|}{ Docente: } \\
\hline \multicolumn{3}{|l|}{ Docente: } \\
\hline \multicolumn{3}{|l|}{ Decente: _ } \\
\hline \multicolumn{3}{|l|}{ Docente: } \\
\hline \multicolumn{3}{|c|}{ 2. LEVANTAMENTO DE TEMAS E DE IDÉIAS PARA PROJETOS } \\
\hline Temas para & ojetos & Idéias Sugeridas de Projetos \\
\hline Bobina Tesla & & $\begin{array}{l}\text { Demonstração de fenômenos onde interferem muito as } \\
\text { altas tensões. (ex:faíscas ruidosas) }\end{array}$ \\
\hline \multicolumn{2}{|c|}{$\begin{array}{l}\text { Relações de } \\
\text { Interdisciplinaridade }\end{array}$} & $\begin{array}{l}\text { UCR1: Eletricidade - 120h } \\
\text { UCR2: Introdução à Informática - 30h } \\
\text { UCR3: Comunicação Oral e Escrita - 30h } \\
\text { UCR4: Eletrônica Básica - 60h } \\
\text { UCR5: Desenho Técnico Elétrico - 60h }\end{array}$ \\
\hline
\end{tabular}




\begin{tabular}{|c|c|c|}
\hline ETAPAS - 1 SEMESTRE & UNIDADES CURRICULARES & $\begin{array}{l}\text { ATIVIDADES A SEREM } \\
\text { DESENVOLVIDAS }\end{array}$ \\
\hline 1 - PESQUISA & Introdução a Informática & $\begin{array}{l}\text { - } \begin{array}{l}\text { Desenvolvimento de } \\
\text { pesquisa e apresentação } \\
\text { de slides dos seguintes } \\
\text { temas, seguindo a } \\
\text { formatação indicada pelo } \\
\text { professor: }\end{array} \\
\text { - Bobina De Tesla } \\
\text { - Eletromagnetismo } \\
\text { - Tensão } \\
\text { - Indutância } \\
\text { - Resistência } \\
\text { - Instrumentos De } \\
\text { Medição }\end{array}$ \\
\hline 2 - DESENHOS & Desenho Técnico Elétrico & $\begin{array}{l}\text { Desenvolver } \\
\text { desenhos manuais } \\
\text { dos componentes e } \\
\text { do circuito elétrico da } \\
\text { bobina de Tesla. }\end{array}$ \\
\hline 3- MATERIAL & Eletrônica Básica & $\begin{array}{l}\text { Especificar os } \\
\text { componentes eletrônicos } \\
\text { necessários para a } \\
\text { montagem do circuito. }\end{array}$ \\
\hline
\end{tabular}




\begin{tabular}{|c|c|c|}
\hline ETAPAS - 10 SEMESTRE & UNIDADES CURRICULARES & $\begin{array}{l}\text { ATIVIDADES A SEREM } \\
\text { DESENVOLVIDAS }\end{array}$ \\
\hline $\begin{array}{l}4 \text { - DIMENSIONAMENTO } \\
\text { ELÉTRICO }\end{array}$ & Eletricidade & $\begin{array}{l}\text { - Dimensionar } \\
\text { componentes do circuito } \\
\text { de Alimentação e } \\
\text { proteção. } \\
\text { - Desenvolver cálculos } \\
\text { matemáticos que } \\
\text { possam ser utilizados no } \\
\text { dimensionamento dos } \\
\text { componentes. }\end{array}$ \\
\hline 5 - FABRICAÇÃO DE PEÇAS & Eletricidade & $\begin{array}{l}\text { - Confecção do Trafo de } \\
\text { M.A.T (das bobinas). }\end{array}$ \\
\hline 6 - MONTAGEM GERAL & Eletrônica Básica & $\begin{array}{l}\text { - Inserção dos } \\
\text { componentes e revisão } \\
\text { do circuito. } \\
\text { - Analisar e montar o } \\
\text { circuito. }\end{array}$ \\
\hline 7 - ACIONAMENTO & Eletrônica Básica & $\begin{array}{l}\text { - Teste e monitoração do } \\
\text { funcionamento. }\end{array}$ \\
\hline 9 - START UP & Comunicação Oral e Escrita & $\begin{array}{l}\text { - Elaboração de relatórios } \\
\text { sobre o desenvolvimento } \\
\text { do projeto. } \\
\text { - Levantamento dos } \\
\text { pontos fortes e fracos do } \\
\text { projeto. }\end{array}$ \\
\hline
\end{tabular}




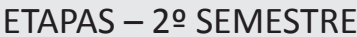

\begin{tabular}{|l|l|l|}
\hline & $\begin{array}{l}\text { Demonstração descargas } \\
\text { atmosféricas através da } \\
\text { Projetos Elétricos } \\
\text { residenciais e prediais }\end{array}$ & $\begin{array}{l}\text { Interpretação de para-raio } \\
\text { Elétrico }\end{array}$ \\
& $\begin{array}{l}\text { Utilização de ferramentas } \\
\text { manuais e ferramentas } \\
\text { Instalações Elétricas em } \\
\text { baixa tensão residenciais e } \\
\text { prediais }\end{array}$ & $\begin{array}{l}\text { da Bobina } \\
\text { damensionamento/ } \\
\text { Confecção e Instalação do } \\
\text { transformador utilizado no } \\
\text { projeto }\end{array}$ \\
\hline
\end{tabular}

ETAPAS - 3 SEMESTRE

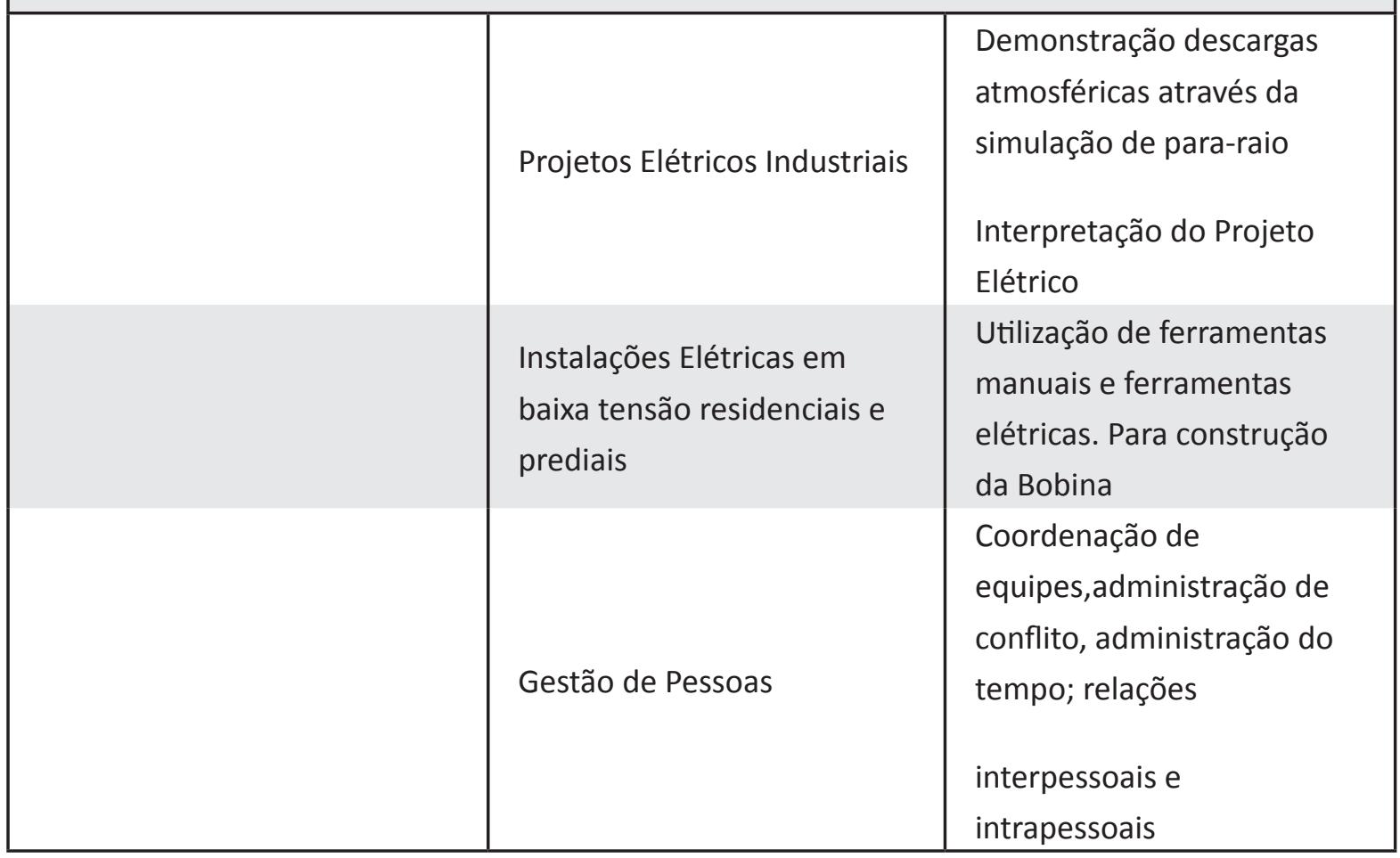




\begin{tabular}{|c|c|}
\hline \multicolumn{2}{|c|}{ Descrição e Análise dos fatores de viabilidade: } \\
\hline FATORES & CONSIDERAÇÕES \\
\hline Interdisciplinaridade & Todas as disciplinas dos 3 semestres. \\
\hline $\begin{array}{l}\text { Tempo: necessário X } \\
\text { disponível }\end{array}$ & $\begin{array}{l}\text { De Fevereiro / } 2010 \text { a Julho/ } 2011 \text { (durante as aulas e tarefas } \\
\text { extra classe). }\end{array}$ \\
\hline Recursos necessários & 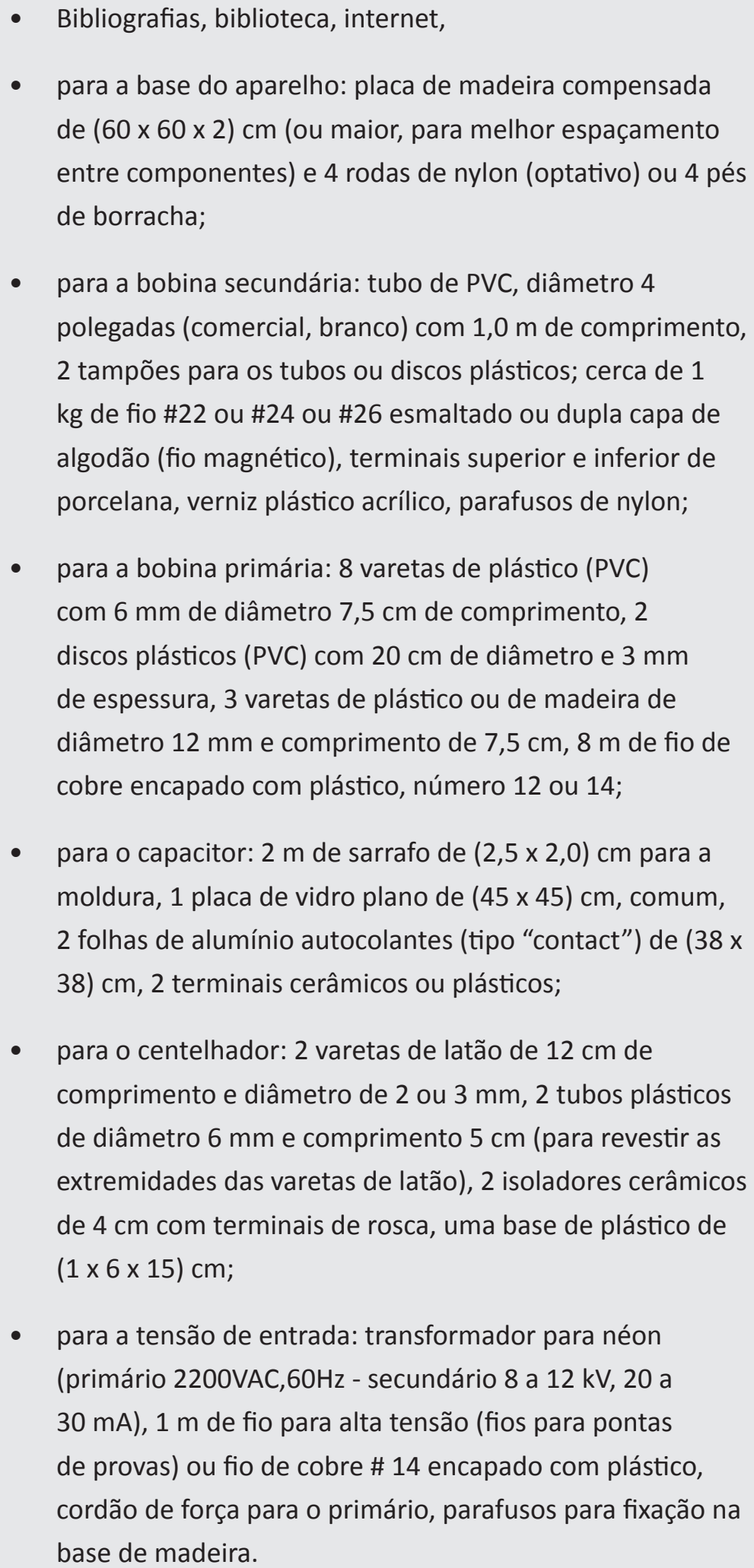 \\
\hline
\end{tabular}


Etapa 2. Definição das Diretrizes para o Projeto

1. EQUIPE DOCENTE RESPONSÁVEL PELA ETAPA:

Coordenador:

Docente:

Docente:

Decente:

Docente:

2. TÍTULO DO PROJETO:

Bobina Tesla

\section{OBJETIVOS DO PROJETO:}

- A relação entre a teoria e prática;

- Integração entre grupos;

- Interdisciplinaridade;

- Produção de Material Didático;

4. SITUAÇÃO - PROBLEMA:

Realizar experimentos relacionados com as altas tensões, com as altas freqüências, com a emissão de ondas de rádio, com os circuitos ressonantes, com as ionizações de gases etc.

\section{RESPONSABILIDADES}

\begin{tabular}{|c|c|}
\hline Agente & Atribuições \\
\hline Alunos: & $\begin{array}{l}\text { - Cumprir o cronograma } \\
\text { - Pesquisa bibliográfica e na internet } \\
\text { - Desenvolver todas as etapas do trabalho } \\
\text { - Apresentação } \\
\text { - Exposição }\end{array}$ \\
\hline $\begin{array}{l}\text { Docente Coordenador do } \\
\text { projeto: }\end{array}$ & $\begin{array}{l}\text { - Acompanhar o projeto } \\
\text { - } \quad \text { Cumprir prazos pré-estabelecidos } \\
\text { - Integração entre professores e alunos }\end{array}$ \\
\hline
\end{tabular}




\section{REGULAMENTOS}

- Cumprir com o cronograma;

- Desenvolver cada etapa do desenvolvimento do produto com orientação do professor da disciplina;

- Apresentar os trabalhos em dia e local determinado as turmas do CTE;

- Fazer a demonstração do produto, em eventos, feiras, mostras.

\section{AVALIAÇÃO}

- Atuação do aluno de forma individual e em equipe;

- Pesquisa;

- Trabalho concluído (peças fabricadas, montagem, funcionamento, melhorias);

- Apresentação;

- Cumprimento dos prazos do cronograma;

- Responsabilidade.

3. RELATÓRIO DO PROJETO INTEGRADOR

O aluno fará um relatório final, dentro das normas da metodologia, descrevendo todas as etapas do trabalho e apresentará aos responsáveis pelo projeto.

1. ORIENTAÇÕES PARA APRESENTAÇÃO DO PROJETO

- Apresentação individual;

- Em powerpoint;

- Demonstração de funcionamento.

2. RECOMENDAÇÕES GERAIS

Coordenador:

Docente:

Docente:

Decente:

Docente: 


\section{Etapa 3. Planejamento da Implementação}

1. EQUIPE DOCENTE RESPONSÁVEL PELA ETAPA:

Coordenador:

Docente:

Docente:

Decente:

Docente:

2. CAPACITAÇÃO/ORIENTAÇÃO ESPECÍFICA AOS ALUNOS

( $x$ ) Trabalhar em Equipe

( ) Técnicas de criatividade

( $x$ ) Métodos para testar hipóteses

( $x$ ) Técnicas de planejamento

( $x$ ) Técnicas de pesquisa

\section{Providências e Responsabilidades}

Providenciar materiais necessários para o desenvolvimento das peças do projeto.

Responsabilidade:

3. CONHECIMENTOS E HABILIDADES A SEREM DESENVOLVIDAS ALÉM DAS ESPECIFICADAS NAS UNIDADES CURRICULARES

\section{Conhecimentos}

1- PROVIDÊNCIAS GERAIS

(Prever o que será necessário para viabilizar o desenvolvimento do projeto: pesquisas, visitas, realização de ensaios, construção de protótipos, etc.)

- Compra dos materiais;

- Reserva de laboratórios; 

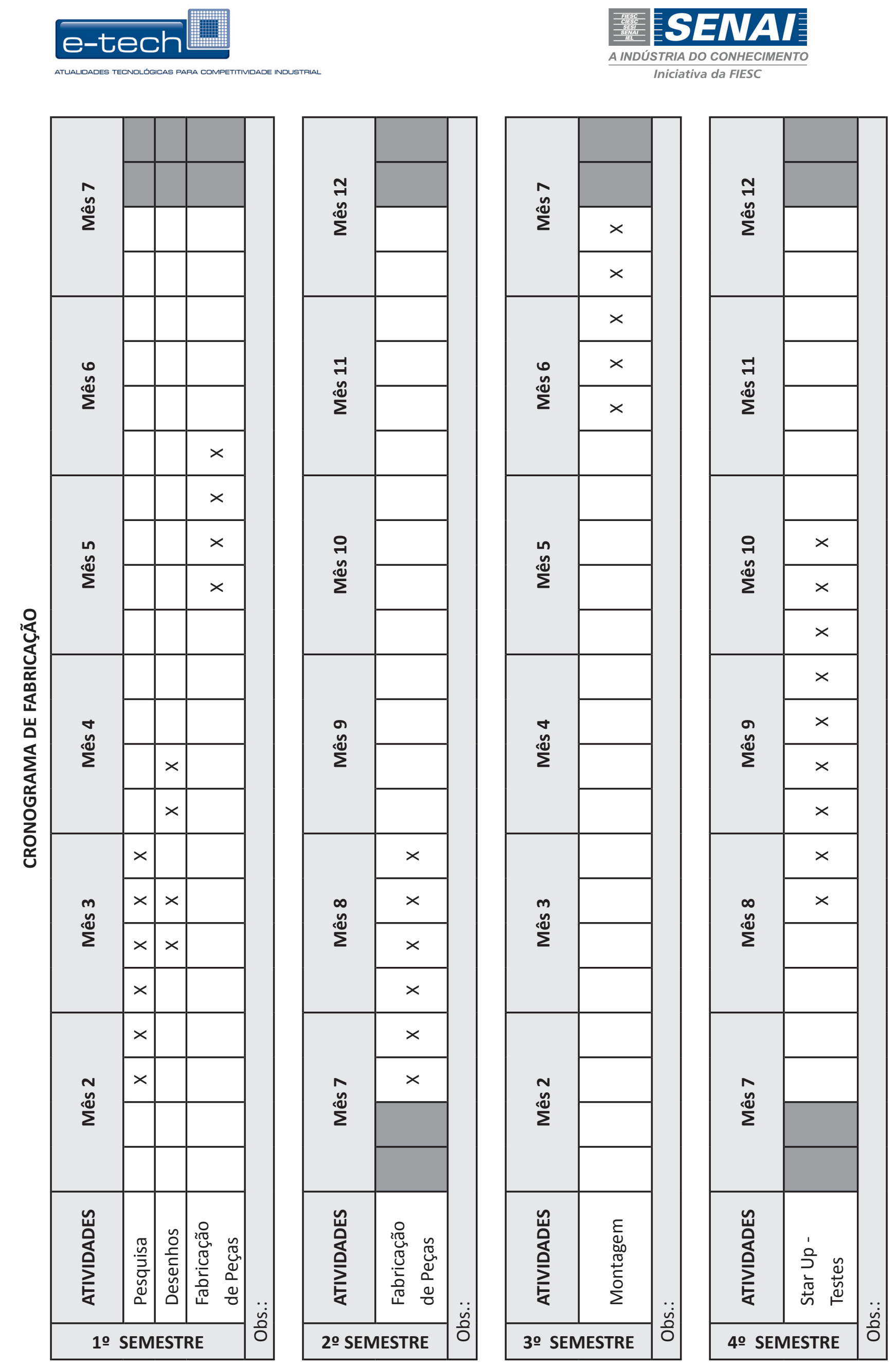